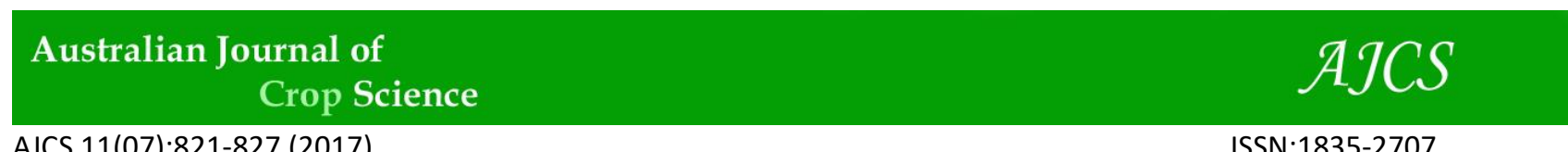

AJCS 11(07):821-827 (2017)

ISSN:1835-2707

doi: 10.21475/ajcs.17.11.07.pne469

\title{
Physiological responses to intense water deficit in two genotypes of crambe (Crambe abyssinica Hochst.)
}

\author{
Rodrigo Fantin Alves Martins ${ }^{1}$, André Felipe Costa Souza ${ }^{1}$, Carlos Pitol ${ }^{2}$, Antelmo Ralph Falqueto ${ }^{1}$ \\ ${ }^{1}$ Departamento de Ciências Agrárias e Biológicas, Centro Universitário Norte do Espírito Santo, Universidade \\ Federal do Espírito Santo, BR 101 Norte, Km. 60, Bairro Litorâneo, CEP 29932-540, São Mateus, Espírito Santo, \\ Brazil \\ ${ }^{2}$ Fundação MS Para Pesquisa e Difusão de Tecnologias Agropecuárias, Estrada da Usina Velha, km 02 - Zona \\ Rural, 79150-000 - Maracaju, MS, Brasil - Caixa-postal: 105
}

*Corresponding author: antelmo.falqueto@ufes.br

\begin{abstract}
Drought stress is a major environmental factor limiting growth and agricultural productivity. The objective of this study was to compare photosynthetic responses to intense water deficit and the recovery capacity in crambe plants (Crambe abyssinica Hochst. cultivar FMS Brilhante and lineage FMS CR1101) using chlorophyll $a$ fluorescence analyses. Plants were submitted to water deficit for seven days followed by rehydration. Chlorophyll $a$ fluorescence measurements were performed using a Handy-PEA fluorometer. Under drought stress, there was a reduction of the leaf relative water content (RWC) and stomatal conductance $\left(\mathrm{g}_{\mathrm{s}}\right)$, with full recovery after three days of rehydration to BRS Brilhante cultivar. Both genotypes showed decreased flux of electrons transport from the absorption to the reduction of the intersystem acceptors. FMS Brilhante cultivar showed better energetic connectivity (L-band) between photosystem II (PSII) units and lower inactivation of the oxygen-evolving complex (K-band), evidencing advantages of the cultivar compared to FMS CR1101 lineage. Finally, the recovery of photosynthetic activity observed in FMS CR1101 lineage during rehydration was due the phenomena related to the electron flow around the PSI.
\end{abstract}

Keywords: Chlorophyll $a$ fluorescence; Drought tolerance; JIP-test; Recovery; Photosystem II.

Abbreviations: $\mathrm{F}_{0}=\mathrm{F}_{20 \mu \mathrm{s}}$, minimum fluorescence, when all PSII RCs are open; F2 (100 $\left.\mu \mathrm{s}\right)$ and F3 (300 $\mu$ s), fluorescence intensity at 100 and $300 \mu \mathrm{s}$, respectively; F4 $(2 \mathrm{~ms})$ and F5 (30 ms), fluorescence intensity at the J-step (2 ms) and the I-step (30 ms), respectively; $\mathrm{F}_{\mathrm{m}}$, maximum fluorescence, when all PSII RCs are closed; $\mathrm{g}_{\mathrm{s}}$, stomatal conductance; RWC, relative leaf water content; $\mathrm{DH}$, days after the onset of drought stress; $\mathrm{RC}$, days after rehydration; $\mathrm{P}_{680}$, reaction center of photosystem $\mathrm{II}$; $\mathrm{PQH}_{2}$, plastoquinol; $\mathrm{CF}$, chlorophyll $a$ fluorescence, OEC, oxygen-evolving complex; PSI, photosystem I; PSII, photosystem II; $\mathrm{Q}_{\mathrm{A}}$, primary quinone acceptor of PSII; RC, reaction centre; ROS, reactive oxygen species; $\mathrm{V}_{\mathrm{t}}$, variable fluorescence between steps $\mathrm{O}(20 \mu \mathrm{s})$ and $\mathrm{P}$; $\mathrm{V}_{\mathrm{OK}}$, variable fluorescence between steps $\mathrm{O}(20 \mu \mathrm{s})$ and $\mathrm{K}(300 \mu \mathrm{s}) ; \mathrm{V}_{\mathrm{OJ}}$, variable fluorescence between steps $\mathrm{O}(20 \mu \mathrm{s})$ and $\mathrm{J}(2 \mathrm{~ms}) ; \mathrm{V}_{\mathrm{IP}}$, variable fluorescence between steps I (30 ms) and P; $\Delta \mathrm{V}$, diference kinetic; TM,turgid mass; DM, dry mass.

\section{Introduction}

Drought stress is a major environmental stress limiting plant growth and agricultural productivity in regions affected by low precipitation (Campos et al., 2014). Decreases in plant growth and productivity are induced by specific metabolic processes such as stomatal conductance, efficiency in the thylakoid electron transport chain and carbon assimilation, which are directly related to water deficit (Waseem et al., 2011). Under drought stress, plants limit their leaf transpiration through stomatal control, avoiding excessive water loss, which can ultimately lead to cellular dehydration and plant death (Chaves et al., 2003). However, reductions of stomatal aperture directly affects $\mathrm{CO}_{2}$ assimilation and, consequently, the plant productivity decreases (Flexas et al., 2004; Lawson and Blatt, 2014). In addition, water deficit results in a direct reduction of both activity and efficiency of photosystem 2 (PSII) (Pinheiro and Chaves, 2011; Souza et al., 2004).

Plant tolerance to water deficit has been shown to be related to specific features. Stomatal conductance $\left(\mathrm{g}_{\mathrm{s}}\right)$ and the relative leaf water content (RWC) are two efficient methods to study plant drought adaptation. Studies about water deficit have shown a high correlation between RWC, leaf area maintenance, and osmotic adjustment (James et al., 2008).

Drought stress has multiple effects on plants. Under water deficit, structural and functional alterations of photosynthetic apparatus can be estimated using the chlorophyll $a$ fluorescence (CF) analysis (Stirbet and Govindjee, 2011; Zushi and Matsuzoe, 2017). The CF is a non-destructive, simple, and rapid testing method used to evaluate the functionality of the photosynthetic apparatus under environmental stress (Chen et al., 2015; Gonçalves et al., 2010; Oukarroum et al., 2007). Under water deficit, CF analysis has been used to monitoring and screening tolerance of species, genotypes and lineages to stress (Campos et al., 2014; Gomes et al., 2012; Oukarroum et al., 2009). Positive L-band and K-band values in barley (Hordeum vulgare L.), passion (Passiflora edulis L.) and in two maize (Zea mays L., cvs. Shaandan 609 and Zhengdan 958) cultivars differing in drought tolerance were described (Gomes et al., 2012; Oukarroum et al., 2007; Zhang et al., 2015), revealing decreased function of oxygen evolving complex (OEC), and decreased energetic connectivity between PSII units. The 
authors observed that after rewatering, signals of recovery occurred, which were attributed to an increase in drought resistance or hardening. Thus, it is possible to use CF measurements to differentiate between drought-resistant and drought-sensitive genotypes at the level of PSII.

Crambe (Crambe abyssinica Hochst, Brassicaceae) is native to the Mediterranean region and Ethiopia and cultivated in some tropical and subtropical regions. Crambe is an annual crop with a high content of erucic acid (55-60\%) in the seed oil (Lazzeri et al., 1994). According to Falasca et al. (2010), under climatic conditions of Brazil, crambe can be cultivated as off-season, after soybean harvest.

In Brazil, FMS Brilhante cultivar is the only registered genotype (Lara-Fioreze et al., 2013), which has been considered to be relatively drought-tolerant. However, in order to increase the yield, news genotypes of crambe have been created by Mato Grosso do Sul Foundation (MS Foundation) through of breeding programs (Pitol et al., 2012). In addition to the increase in yield and improvement in oil quality, crambe breeding programs aimed to obtain plants with higher levels of stress tolerance, such as drought deficit. Thus, the use of tolerant cultivars to low water availability should be an alternative to increase the productivity, allowing us to expand the culture to other promising regions around the world. According to Wasseen et al. (2011), crop tolerance to drought stress requires the ability of maintenance of vital functions of the cellular metabolism under conditions of water deficit as well as rapid recovery of water status and plant function after stress. Among the recent crambe genotypes, the FMS CR1101 lineage has been shown similar yield to the FMS Brilhante cultivar (approximately 1280 kg.ha ${ }^{-1}$ and $1254 \mathrm{~kg} \cdot \mathrm{ha}^{-1}$, respectively) under unstressed conditions (Oliveira et al., 2015). However, no records exist regarding the physiological performance of FMS CR1101 lineage under low water availability in Brazil. In general, studies with crambe are focused on seed storage, germination, and oil quality (Martins et al., 2011; Teixeira et al., 2011). The knowledge about the physiological performance of a specific genotype submitted to water stress give us the base to expand the culture to regions characterized by low precipitation. The use of genotypes well adapted to low water availability is a viable alternative to improve higher productivity under climatic conditions of region. The responses to drought are species specific and often genotype specific.

The aim of this study was to compare the immediate photosynthetic responses to intense water deficit and the recovery capacity in crambe plants (cultivar FMS Brilhante and lineage FMS CR1101) both in terms of stomatal conductance and of the functionality of the photossynthetic apparatus, as assessed by chlorophyll $a$ fluorescence transient measurements.

\section{Results and Discussion}

\section{Leaf water parameters}

Reduction of soil water availability during water deficit resulted in a significant reduction of the leaf relative water content (RWC) in both genotypes studied (Fig. 1A and 1B). However, we observed a stronger reduction of RWC in FMS CR1101 at DH 4 (Fig. 1B). RWC values were similar between cultivar and lineage on day of maximal stress (DH 7). Total recovery of RWC values were observed only to FMS brilhante cultivar, which occurred 3 days after rehydration (RC 3) of the plants (Fig. 1A and 1B).
Stomatal conductance $\left(\mathrm{g}_{\mathrm{s}}\right)$ decreased significantly with the water deficit (Fig. 1C and 1D). However, after 4 days of water suppression, higher reductions of $\mathrm{g}_{\mathrm{s}}$ values was observed in FMS CR1101lineage, which remained constant until the $1^{\text {st }}$ day of rehydration, RC 1 (Fig. 1D). In addition, some recovery signals of $g_{s}$ values were observed only at RC 3 in FMS CR1101 lineage. Total recovery of $g_{s}$ was observed at RC 3 only in FMS Brilhante cultivar (Fig. 1C). Table 1 shows the analysis of variance for relative water content (RWC) and stomatal conductance $\left(\mathrm{g}_{\mathrm{s}}\right)$.

Stomatal closure is one of the first plant responses to water deficit, reducing water loss by transpiration (Claeys and Inzé, 2013; Lawson and Blatt, 2014). Hence, the fast RWC and $\mathrm{g}_{\mathrm{s}}$ decrease observed in FMS CR1101 lineage since DH 4 suggests higher sensibility to water deficit. On the other hand, in FMS Brilhante cultivar, RWC and $g_{s}$ values have decreased more slightly, indicating that this crambe cultivar is able to maintain the leaf water status during drought stress.

\section{Chlorophyll a fluorescence transient OJIP}

Chlorophyll $a$ fluorescence transient OJIP represents the successive reduction process of the electron transporters associated with photosystems during the photochemical reactions of plant photosynthesis. In this study, both cultivar and lineage showed a typical polyphasic rise in $\mathrm{CF}$, from $\mathrm{F}_{\mathrm{O}}$ to $F_{P}$, with intermediate points $F_{J}$ and $F_{I}$ well defined (Fig. $2 \mathrm{~A}$ and $2 \mathrm{~B}$ ). This result is an indicative that all evaluated samples are photosythetically active (Strasser and Strasser, 1995). OJIP curves were similar between genotypes until the $4^{\text {th }}$ day of water deficit (DH 4). However, on day of maximal stress (DH 7), suppression and inhibition of all OJIP phases in both genotypes was observed, mainly in the FMS Brilhante crambe cultivar (Fig. 2A and 2B). The decrease of CF curves and the suppression of the OJIP phases indicate partial or total blockages of the photosynthetic electron transport in response to stress (Mehta et al., 2010).

To FMS Brilhante crambe cultivar, increases of the initial fluorescence $\left(F_{O}\right)$ and a reduction of $F_{J}, F_{I}$ and $F_{P}$ steps were observed on the day of maximum stress (DH 7), compared with the other days of treatment. On the other hand, FMS CR1101 lineage showed also an increase of $F_{O}$ on DH 7, but maintained similar $F_{J}$ step while $F_{I}$ and $F_{P}$ steps decreased (Fig. 2A and 2B). By comparing the genotypes, the FMS Brilhante cultivar was characterized by a major reduction of $F_{I}$ e $F_{P}$ steps. After the rehydration, total recovery of the OJIP phases occurred for all plants.

The fluorescence data between $\mathrm{O}$ and $\mathrm{P}$ steps was analyzed through of difference kinetic profile $\Delta \mathrm{V}_{\mathrm{t}}=\left[\mathrm{V}_{\mathrm{t}}\right.$ (treatment) $-\mathrm{V}_{\mathrm{t}}$ (control) (Fig. 2C and 2D). These normalizations allowed to better evaluating the polyphasic behavior of the OJIP curves for the events reflected in the O-J, J-I and I-P phases (Strasser and Strasser, 1995). The analysis of $\Delta \mathrm{V}_{\mathrm{t}}$ permits us to localize the actions site of water stress in electron transport chain on acceptor side of PSII. In this study, the $\Delta \mathrm{V}_{\mathrm{t}}$ analysis evidenced the appearance of positive bands during water deficit imposition. Higher variation of $\Delta \mathrm{V}_{\mathrm{t}}$ was observed at DH 7 compared to control in both crambe cultivar and lineage (Fig. 2C and 2D).

These results are an indicative of damage of the electron transporters localized on the intersystem. However, in FMS CR1101 lineage, the slope of $\Delta \mathrm{V}_{\mathrm{t}}$ increased from $\mathrm{F}_{0}$ to $\mathrm{F}_{\mathrm{I}}$ (Fig. 2D). In FMS Brilhante crambe cultivar, increases of $\Delta \mathrm{V}_{\mathrm{t}}$ were observed only between $\mathrm{F}_{\mathrm{J}}$ and $\mathrm{F}_{\mathrm{I}}$ (Fig. 2C), suggesting the occurrence of higher damage in FMS CR1101 lineage, ranging from $\mathrm{Q}_{\mathrm{A}}$ reduction to intersystem reduction events. Furthermore, decreases of $\Delta \mathrm{V}_{t}$ on I-P phase was 
Table 1. Analysis of variance for leaf relative water content (RWC) and stomatal conductance $\left(\mathrm{g}_{\mathrm{s}}\right)$ in $C$. abyssinica FMS Brilhante (cultivar) and FMS CR1101 (lineage) submitted to water deficit and recovery. F values, significance levels (p) and the coefficient of variation $(\mathrm{CV})$ are presented for each parameter.

\begin{tabular}{|c|c|c|c|c|c|c|c|c|}
\hline \multirow[b]{3}{*}{ RWC } & \multicolumn{4}{|c|}{ FMS BRILHANTE cultivar } & \multicolumn{4}{|c|}{ FMS CR1101 lineage } \\
\hline & $F$ & $p$ & $C V(\%)$ & Significance & $F$ & $p$ & $C V(\%)$ & Significance \\
\hline & 18.692 & 0.0001 & 11.76 & $* *$ & 32.298 & 0.0001 & 10.28 & $* *$ \\
\hline $\mathrm{g}_{\mathrm{s}}$ & 2.757 & 0.0278 & 25.02 & * & 7.284 & 0.0001 & 26.73 & ** \\
\hline
\end{tabular}
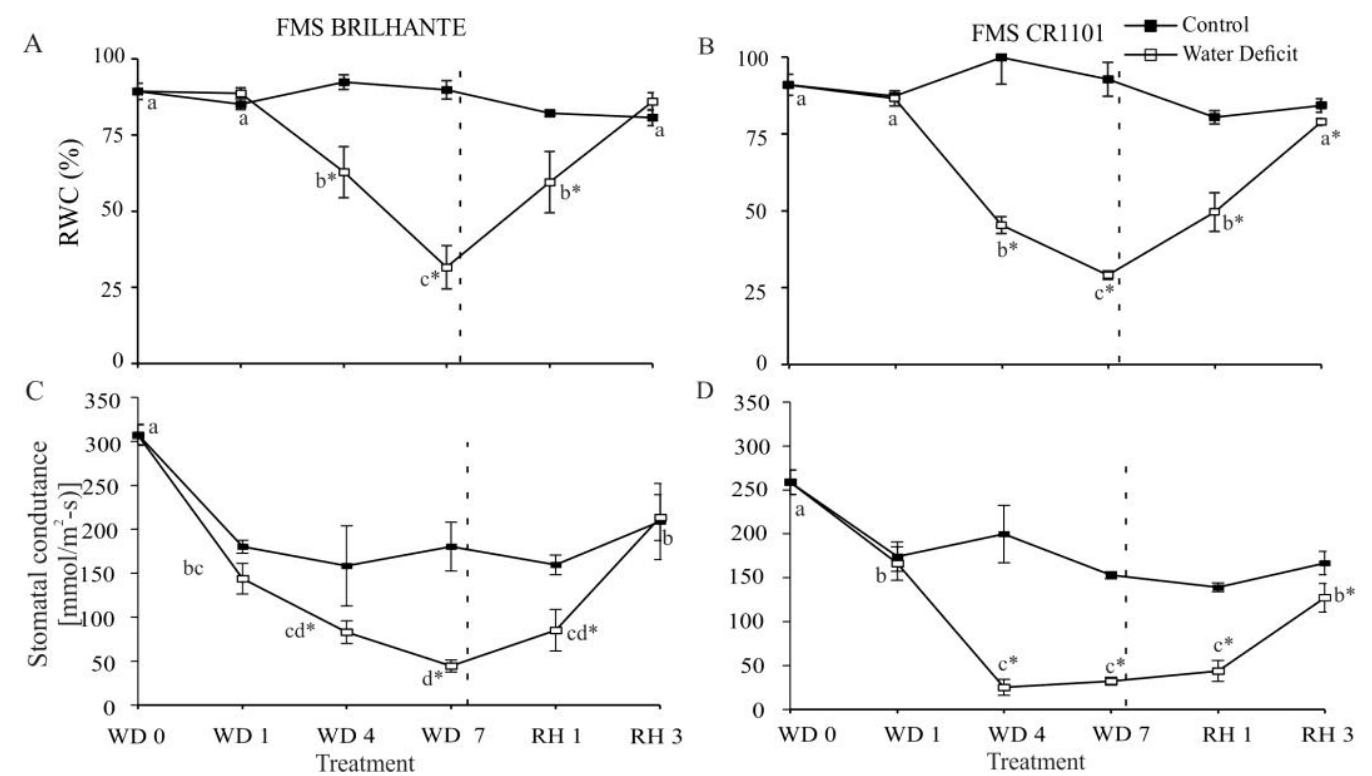

Fig 1. Relative leaf water content (RWC) and stomatal conductance $\left(\mathrm{g}_{\mathrm{s}}\right)$ in $C$. abyssinica FMS Brilhante cultivar (A and C) and FMS CR1101 lineage (B and D) submitted to water deficit and rehydration. Dashed line indicates the end day of water deprivation and onset of rehydration. DH 0, 1, 4, 7 - days of water deficit; RC 1, 3 - Days of rehydration. Letters represent the statistical difference between days and the asterisk $(*)$ between treatments (Tukey, $\mathrm{p} \leq 0.05$ ). Values are means for ten plants $( \pm$ standard error).
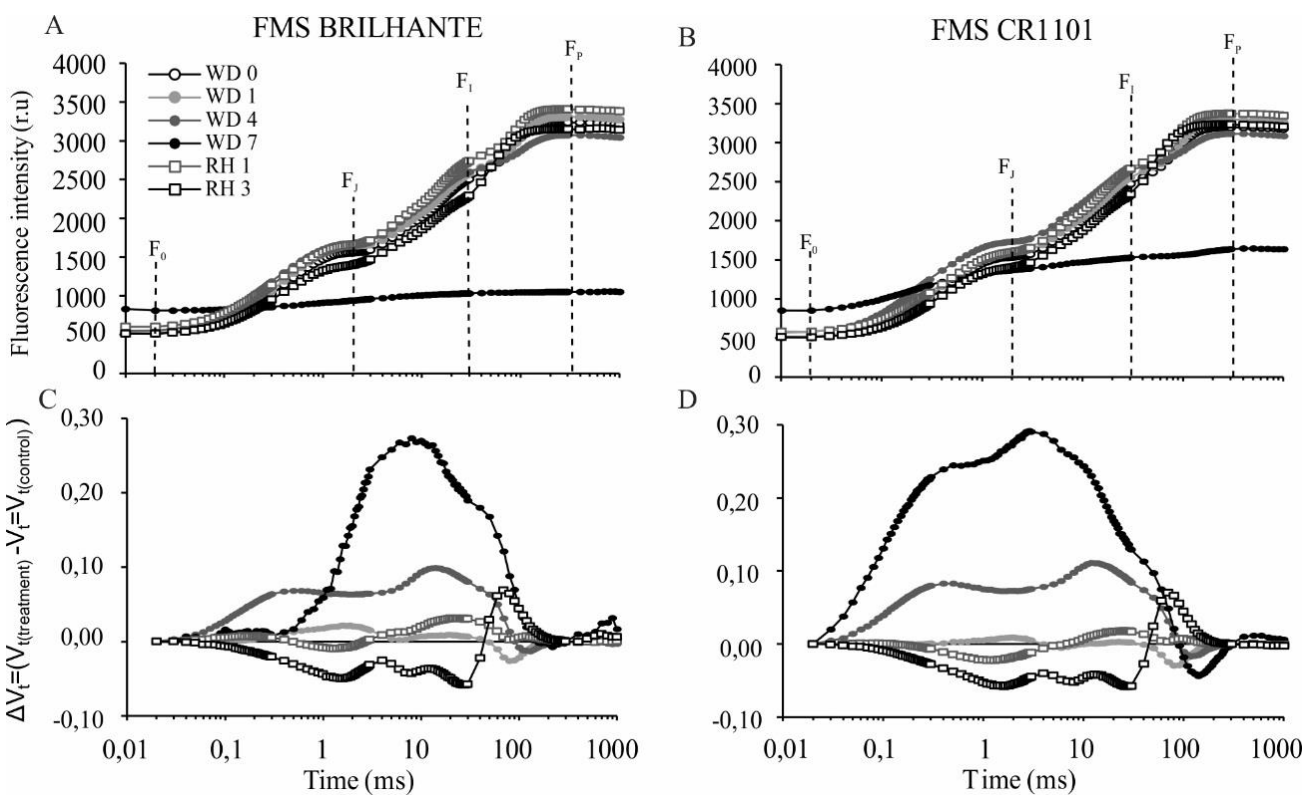

Fig 2. Kinetics of chlorophyll $a$ fluorescence emission between $\mathrm{O}$ and $\mathrm{P}$ steps in leaves of $C$. abyssinica dark pre-adapted, FMS Brilhante cultivar (A and C) and FMS CR1101 lineage (B and D) submitted to water deficit and rehydration. A,B - Fluorescence Intensity $\left(F_{t}\right)$, evidencing the $F_{O}, F_{J}, F_{I}$ and $F_{P}$ step, obtained at $20 \mu \mathrm{s}, 2 \mathrm{~ms}, 30 \mathrm{~ms}$ and $300 \mathrm{~ms}$, respectively. C,D - Kinetic different $V_{t}$ : $\Delta \mathrm{V}_{\mathrm{t}}=\left[\mathrm{V}_{\mathrm{t}(\text { treatment })}-\mathrm{V}_{\mathrm{t}(\text { control })}\right]$. Values are means for ten plants. 

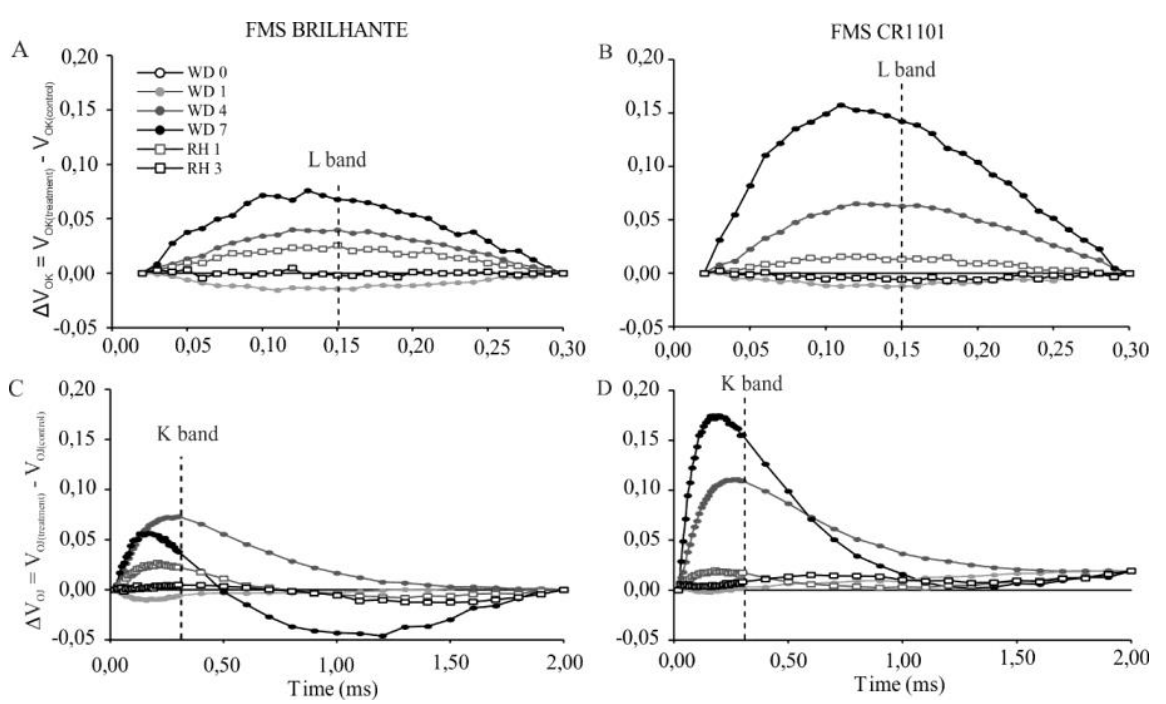

Figure 3 - Kinetic differences of $\mathrm{V}_{\mathrm{OK}}$ and $\mathrm{V}_{\mathrm{OJ}}$ obtained after double normalization between the steps $\mathrm{O}-\mathrm{K}\left[\Delta \mathrm{V}_{\mathrm{OK}}=\right.$ $\left.\mathrm{V}_{\mathrm{OK}(\text { treatment) }}-\mathrm{V}_{\mathrm{OK} \text { (control) }}\right]$ and $\mathrm{O}-\mathrm{J}\left[\Delta \mathrm{V}_{\mathrm{OJ}}=\mathrm{V}_{\mathrm{OJ}(\text { treatment })}-\mathrm{V}_{\mathrm{OJ}(\text { control })}\right]$, respectively, in crambe leaves cultivar FMS Brilhante (A and C) and FMS CR1101 lineage (B and D) submitted to an imposed water stress period and recovery upon rewatering. Before the measurements, leaves were dark-adapted for $30 \mathrm{~min}$. Values are means for ten plants.
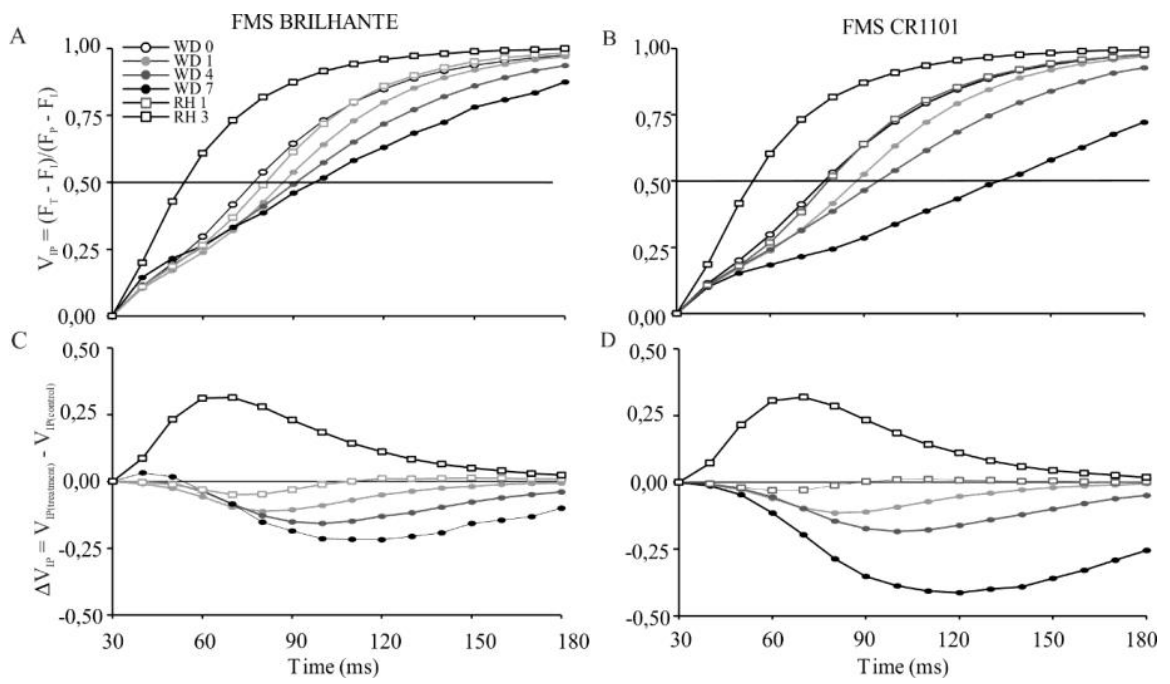

Fig 4. Chlorophyll $a$ fluorescence transient between I and $\mathrm{P}$ steps in leaves of $C$. abyssinica dark pre-adapted, FMS Brilhante cultivar (A and C) and FMS CR1101 lineage (B and D), submitted to water deficit and rehydratation. A,B - variable fluorescence between I and $\mathrm{P}$ steps $\left[\mathrm{V}_{\mathrm{IP}}=\left(\mathrm{F}_{\mathrm{t}}-\mathrm{F}_{\mathrm{I}}\right) /\left(\mathrm{F}_{\mathrm{P}}-\mathrm{F}_{\mathrm{I}}\right)\right]$. C,D - kinetic difference of $\mathrm{V}_{\mathrm{IP}}\left[\Delta \mathrm{V}_{\mathrm{IP}}=\mathrm{V}_{\mathrm{IP}(\text { treatment })}-\mathrm{V}_{\mathrm{IP}(\text { control })}\right]$. Values are means for ten plants.

observed, which was more evident in FMS CR1101 crambe lineage (Fig. 2C and 2D). Similar results were recorded by Gomes et al. (2012) studding passion fruit plants (Passiflora edulis Sims.) growing under water deficit deprivation under greenhouse conditions. According to authors, the decreases of $\Delta \mathrm{V}_{\mathrm{t}}$ on I-P phase is an indicative of a higher end electron acceptor pool of PSI which suggest an increment of the efficiency in which an electron is transferred to the PSI acceptor side.

The relative fluorescence between $\mathrm{F}_{0}$ and $\mathrm{F}_{\mathrm{K}}$ [20 and 300 $\mu \mathrm{s}$, respectively $\left.=\mathrm{V}_{\mathrm{OK}}=\left(\mathrm{F}_{\mathrm{t}}-\mathrm{F}_{\mathrm{O}}\right) /\left(\mathrm{F}_{\mathrm{K}}-\mathrm{F}_{\mathrm{O}}\right)\right]$ and between $\mathrm{O}$ and $\mathrm{J}\left[20 \mu \mathrm{s}\right.$ and $2 \mathrm{~ms}$, respectively $\left.=\mathrm{V}_{\mathrm{OJ}}=\mathrm{F}_{\mathrm{t}}-\mathrm{F}_{\mathrm{O}}\right) /\left(\mathrm{F}_{\mathrm{J}}-\right.$ $\left.\mathrm{F}_{\mathrm{O}}\right)$ ] was normalized and show the kinetic difference $\Delta \mathrm{V}_{\mathrm{OK}}=$ $\mathrm{V}_{\mathrm{OK}(\text { treatment) }}-\mathrm{V}_{\mathrm{OK} \text { (control) }}$ and $\Delta \mathrm{V}_{\mathrm{OJ}}=\mathrm{V}_{\mathrm{OJ}(\text { treatment) }}-\mathrm{V}_{\mathrm{OJ} \text { (control), }}$ respectively (Fig. 3). The difference kinetic $\Delta \mathrm{V}_{\mathrm{OK}}$ and $\Delta \mathrm{V}_{\mathrm{OJ}}$ reveal, respectively, the L-band (Fig. $3 \mathrm{~A}$ and $3 \mathrm{~B}$ ) and the $\mathrm{K}$ band (Fig. 3C and 3D). In this study, we observed the appearance of positive L-band from DH 4 with maximum values obtained at DH 7 in both cultivar and lineage (Fig. 3A and $3 \mathrm{~B}$ ). However, the slope of L-band was more evident in FMS CR1101 lineage at DH 4 and DH 7, i.e., 0.05 and 0.15, respectively (Fig. 3B). L-band is interpreted such as energetic connectivity between PSII units (Tsimilli-Michael and Strasser, 2008; Oukarroum et al., 2007). Thus, the results obtained here show that the water deficit caused higher disturbances of the energetic connectivity in FMS CR1101 lineage compared to FMS Brilhante crambe cultivar (Fig. 3B). Also, positives K-band was recorded in response to 
water deficit in both crambe genotypes from DH 4 (Fig. 3C and 3D). K-band is related to the electron donor side of PSII and, when positive, may indicate the inactivation of the OEC (Yusuf et al., 2010). Thus, the transference of electrons from the OEC to the reaction center $\mathrm{P}_{680}$ is slower than the transference of electrons from $\mathrm{P}_{680}$ to quinone $\mathrm{A}, \mathrm{Q}_{\mathrm{A}}$ (JIANG et al., 2008). In the present study, the K-band increased hyperbolically in FMS CR1101 lineage reaching higher values (approximately 0.17 at $\mathrm{DH} 7$ ) than those obtained in FMS Brilhante cultivar after 4 days of water deficit, DH 4 (Fig. 3D). The results obtained regarding L- and K-bands suggest that FMS Brilhante has a higher ability to maintain OEC activity and energetic stability under drought stress. Nonetheless, both the cultivar and lineage showed recovery of K- and L-band values. According to Strasser et al. (2004), recovery of $\Delta \mathrm{V}_{\mathrm{OK}}$ is related to plant tolerance to drought stress, since a high connectivity among the PSII units lead to a more efficient use of excitation energy and higher system stability.

The variable transient fluorescence between $F_{I}$ and $F_{P}$ steps is shown as $V_{I P}$ and $\Delta V_{I P}$ between 30 and $180 \mathrm{~ms}$ (Fig. 4), which permit us to evaluate the behavior of the electron flux reaching the acceptors of photosystem I (PSI). $V_{\text {IP }}$ gradually decreased with water deficit (from DH 4 to DH 7), with the lowest values observed in the FMS CR1101 lineage (Fig. 4B). However, the plant rehydration resulted in increased $V_{I P}$ curves in both genotypes, with higher values obtained after 3 days of rehydration (RC 3). According to Yusuf et al. (2010), the inverse time to reach $V_{\text {IP }}=0.5$ is an estimate of the global reduction rate of the end electron acceptors of PSI. Thus, the results obtained in this study revealed the occurrence of a decrease of the time required to reduce the end electron acceptors on the day of maximal stress (DH 7) in both genotypes. Redillas et al. (2011) evaluating the photosynthetic responses of transgenic rice plants to water deficit, concluded that the rice genotype considered to be more tollerant to water deficit had the highest slopes on phase I-P. A slope reduction on phase I-P seems to indicate a typical response of plants to certain stress conditions considering the increased efficiency to which an electron is transferred to the acceptor side of the PSI (Yusuf et al., 2010). These results suggest that the electron flow after $\mathrm{PQH}_{2}$ was less sensitive to water deficit than the electron flow between $\mathrm{Q}_{\mathrm{A}}$ and $\mathrm{PQH}_{2}$ in FMS CR1101 lineage. The analysis of $\mathrm{V}_{\mathrm{IP}}$ and $\Delta \mathrm{V}_{\mathrm{IP}}$ illustrate the effects of water stress on the reduction rates and acceptors electron pool size associated to PSI. Finally, the results obtained in this study suggest that the regulation of the end acceptors of PSI occur independently of acceptors pool size associated to PSI. Yusuf et al. (2010) have reported similar results in transgenic plants of Brassica juncea exposed to saline stress, heavy metals, and osmotic stress. Such results give us evidences about mechanisms increasing the activity of PSI, such as cyclic electron flow around PSI or the Mehler reaction (Campos et al., 2014; Schock et al., 2014). The importance of these mechanisms is protection against photo-oxidation through of conduction of electron to alternative via that prevent the formation of oxigen reactive (Miyake, 2010; Oukarroum et al., 2015).

\section{Materials and methods}

\section{Plant material and Experimental design}

Seeds of Crambe abyssinica Hochst., FMS Brilhante (cultivar) and FMS CR1101 (lineage) were obtained from Mato Grosso do Sul Foundation (MS Foundation), Maracaju/MS. The experiment was conducted in greenhouse conditions with an averaged midday photosynthetic photon flux (PPF) of $800 \mu \mathrm{molm}^{-2} \mathrm{~s}^{-1}$ situated at the Universidade Federal do Espírito Santo, ES, Brazil. Plant were cultivated on 5.5 L pots (one seedling per pot) filled with soil:sand:cultural substrate (3:2:1). Previously, chemical analyze of soil was made in order to correct nutrient and $\mathrm{pH}$, following the recommendations of Oliveira et al. (1991). The plants were watered daily with automatic sprinkling and cultivated until 28 days old, when the water deficit regime started to be imposed. For each genotype, 40 plants with a similar shoot length ( $30 \mathrm{~cm}$ tall, vegetative grow state) were selected and split in two groups: 20 were maintained with daily irrigation to keep soil close to field capacity (used as control) and the remaining were subjected to progressive drought by withholding watering until stomatal conductance reached values lowest than $50 \mathrm{mmol} \mathrm{m} \mathrm{m}^{2} \cdot \mathrm{s}^{-1}$. This occurred after 7 days without irrigation when the plants showed visual symptoms of predawn wilting. All sampling and measurements were conducted between 4:30 and 7 a.m. using completely expanded leaves from the third or fourth leaf from the apex.

\section{Evaluation of leaf relative water content (RWC) and stomatal conductance $\left(g_{s}\right)$}

Leaf relative water content (RWC) was measured in the morning $(4: 30-6: 00$ a.m.) in five plants of each treatment randomly selected. From each plant, the leaf was removed from which five discs $\left(0.78 \mathrm{~cm}^{2}\right)$ was extracted. The five discs were weighted together, immediately after the colected from the leaves, obtaining the fresh mass of the tissue (FM). RWC was determined following the methods proposed by Barrs and Weatherley (1962). After, the turgid mass (TM) was obtained after the hydration of the foliar discs through of submersion for 24 hours in Petri dishes contend distilled water. Dry mass (DM) was obtained after drying the leaf discs during $72 \mathrm{~h}$ under $65^{\circ} \mathrm{C}$. RWC was calculated according to the following expression and the results expressed in percentage $(\%):$ RWC $=[(\mathrm{FM}-\mathrm{DM}) /(\mathrm{TM}-\mathrm{DM})] * 100$. The stomatal conductance $\left(\mathrm{g}_{\mathrm{s}}\right)$ were measured on the abaxial leaf surface of five plants/treatment using a leaf porometer (SC1Leaf Porometer, Decagon devices).

\section{Chlorophyll a fluorescence measurements}

Fluorescence signals were registered using a Plant Efficiency Analyzer (Handy-PEA, Hansatech, King's Lynn, Northfolk, England) as described by Strasser \& Strasser (1995). Before the measurements, 10 leaves per treatment were adapted to the dark with leafclips (Hansatech, UK) for 20 minutes. Light intensity reaching the leaf was $3000 \mu \mathrm{mol}$ (photons) $\mathrm{m}^{-2} \mathrm{~s}^{-1}$, which was sufficient to generate maximal fluorescence for all the treatments. The fast fluorescence kinetics $\left(\mathrm{F}_{\mathrm{o}}\right.$ to $\left.\mathrm{F}_{\mathrm{m}}\right)$ was recorded from $10 \mu \mathrm{s}$ to $1 \mathrm{~s}$. The fluorescence intensity at 20 $\mu \mathrm{s}$ (considered as $\left.\mathrm{F}_{\mathrm{o}}\right), 100 \mu \mathrm{s}, 300 \mu \mathrm{s}, 2 \mathrm{~ms}\left(\mathrm{~F}_{\mathrm{J}}\right), 30 \mathrm{~ms}\left(\mathrm{~F}_{\mathrm{I}}\right)$ and maximum fluorescence or $\mathrm{F}_{\mathrm{m}}$ were collected and used to obtain the parameters from JIP-test (Tsimilli-Michael; Strasser, 2008). Fluorescence transient curves OJIP were normalized following (Yusuf et al., 2010).

\section{Statistical analysis}

We analyzed 20 pot seedlings per treatment in a completely randomized design. Experiment were performed with $10(\mathrm{CF}$ measurements) and 5 (stomatal conductance and RWC) replicates. Variable data evaluated were submitted to the normalizing test of Shapiro-Wilk. All statistical analysis was 
conducted using the statistical software Assistat version 7.7. Significant differences between the treatments and the control were evaluated using Analysis of Variance (ANOVA) and Tukey's test at a significance level $(\mathrm{p} \leq 0.05)$.

\section{Conclusion}

The results obtained in this study demonstrate that the two genotypes evaluated, cultivar and lineage, showed tolerance to water deficit. Furthermore, both genotypes recovered after rehydration. However, they showed different responses. RWC and $\mathrm{g}_{\mathrm{s}}$ decreased more drastically in FMS CR1101 lineage during water deficit treatments. In addition, the FMS Brilhante crambe cultivar showed better stability and functionality of PSII during water deficit. These results evidence advantages of FMS Brilhante cultivar when compared to FMS CR1101 lineage. Also, our data suggest that the significant recovery observed in FMS CR1101 lineage during rehydration was due the phenomena related to the electron flow around the PSI.

\section{Acknowledgement}

The authors are grateful to $\mathrm{CNPq}$ - Conselho Nacional de Desenvolvimento Científico e Tecnológico (National Counsel of Technological and Scientific Development) for the financial support and scholarship. We are also thankful to Fundação MS (MS Foundation) for providing the necessary plant material and technical support during the study.

\section{References}

Barrs HD, Weatherley PE (1962) A re-examination of the relative turgidity technique for estimating water deficits in leaves. Aust J Biol Sci. 15 (3) 413-428.

Campos H, Trejo C, Peña-Valdivia CB (2014) Photosynthetic acclimation to drought stress in Agave salmiana Otto ex Salm-Dyck seedlings is largely dependent on thermal dissipation and enhanced electron flux to photosystem I. Photosynth Res. 122 (1) 23-39.

Chaves M, Maroco J, Pereira J (2003) Understanding plant responses to drought - from genes to the whole plant. Funct Plant Biol. 30 (3) 239-264.

Chen S, Kang Y, Zhang M, Wang X, Strasser RJ, Zhou B, Qiang S (2015) Differential sensitivity to the potential bioherbicide tenuazonic acid probed by the JIP-test based on fast chlorophyll fluorescence kinetics. Environ Exp Bot. 112 (1) $1-15$.

Claeys H, Inzé D (2013) The Agony of Choice: How Plants Balance Growth and Survival under Water-Limiting Conditions. Plant Physiol. 162 (4) 1768-79.

Colodetti TV, Martins LD, Rodrigues WN (2012) Crambe: aspectos gerais da produção agrícola. Enciclopédia Biosfera. 8 (14) 258-269.

Falasca SL, Flores N, Lamas MC, Carballo SM, Anschau A (2010).Crambe abyssinica: an almost unknown crop with a promissory futureto produce biodiesel in Argentina. Int $\mathrm{J}$ Hydrogen Energy 35:5808-5812.

Flexas J, Bota J, Loreto F, Cornic G, Sharkey TD (2004) Diffusive and metabolic limitations to photosynthesis under drought and salinity in C3 plants. Plant Biol. 6 (3) 269279.

Gomes MTG, Da Luz AC, Dos Santos MR, Batitucci MCP, Silva DM, Falqueto AR (2012) Drought tolerance of passion fruit plants assessed by the OJIP chlorophyll $a$ fluorescence transient. Sci. Hortic. 142 (1) 49-56.

Gonçalves ER, Ferreira VM, Silva JV, Endres L, Barbosa TP, Duarte WG (2010) Trocas gasosas e fluorescência da clorofila $a$ em variedades de cana-de-açúcar submetidas à deficiência hídrica. Rev bras eng agríc ambient 14 (4) 378386.

James AT, Lawn RJ (2008) Cooper, M. Genotypic variation for drought stress response traits in soybean. II. Interrelations between epidermal conductance, osmotic potential, relative water content, and plant survival. Aust J Agric Res. 59 (7) 670-678.

Jiang HX, Chen LS, Zheng JG, Han S, Tang N, Smith BR (2008) Aluminum-induced effects on Photosystem II photochemistry in Citrus leaves assessed by the chlorophyll $a$ fluorescence transient. Tree Physiol. 28 (12) 1863-1871.

Lara-Fiorezea ACC, Tomaza CA, Fiorezea SL, Pilonb C, Zanotto MD (2013) Genetic diversity among progenies of Crambe abyssinica Hochst forseed traits. Ind Crops Prod. 50:771-775.

Lawson T, Blatt MR (2014) Stomatal size, speed, and responsiveness impact on photosynthesis and water use efficiency. Plant Physiol. 164 (4) 1556-70.

Lazzeri L, Leoni O, Conte L, Palmieri S (1994) Some technological characteristics and potential uses of Crambe abyssinica products. Ind Crops Prod. 3 (1-2) 103-112.

Martins LD, Costa FP, Lopes JC (2011) Light influence on seed germination of Crambe (Crambe abyssinica Hochst.). Nucleus (Calcutta). 8 (1) 405-412.

Mehta P, Jajoo A, Mathur S, Bharti S (2010) Chlorophyll $a$ fluorescence study revealing effects of high salt stress on Photosystem II in wheat leaves. Plant Physiol Biochem. 48 (1) $16-20$.

Miyake C (2010) Alternative electron flows (water-water cycle and cyclic electron flow around PSI) in photosynthesis: molecular mechanisms and physiological functions. Plant Cell Physiol. 51 (12) 1951-63.

Oliveira AJ, Garrido WE, Araujo JD, Lourenço S (1991) Métodos de pesquisa em fertilidade do solo. EMBRAPASEA, Brazil,. 392p.

Oukarroum A, El Madidi S, Schansker G, Strasser RJ (2007) Probing the responses of barley cultivars (Hordeum vulgare L.) by chlorophyll $a$ fluorescence OLKJIP under drought stress and re-watering. Environ Exp Bot. 60 (3) 438-446.

Oukarroum A, Schansker G, Strasser RJ (2009) Drought stress effects on photosystem I content and photosystem II thermotolerance analyzed using $\mathrm{Chl} a$ fluorescence kinetics in barley varieties differing in their drought tolerance. Physiol Plant. 137 (2) 188-99.

Oukarroum A, Bussotti F, Goltsev V, Kalaji HM (2015) Correlation between reactive oxygen species production and photochemistry of photosystems I and II in Lemna gibba L. plants under salt stress. Environ Exp Bot. 109 (1) 80-88.

Oliveira RC, Reis ACCS, Agriar CG, Viecelli CA, Primieri C, Tomasi GA, Bleil Junior HG, Andrade MAA, Viana OH (2015). Agroindustrialização do Crambe. 2nd ed. Assoeste, Paraná, Brazil.

Pinheiro C, Chaves MM (2011) Photosynthesis and drought: can we make metabolic connections from available data? J Exp Bot. 62 (3) 869-82.

Pitol C, Roscoe R, Erbes EJ, Romeiro TS, Santos JF (2012) Cultura do Crambe: Resultados e Experimentação. In: FMS (ed) Tecnologia e produção: milho safrinha e culturas de inverno. Fundação MS, Brazil. 145-150.

Redillas MCFR, Strasser RJ, Jeong JS, Kim YS, Kim JK (2011) The use of JIP test to evaluate drought-tolerance of transgenic rice overexpressing OsNAC10. Plant Biotechnol Rep. 5 (2) 169-175.

Schock AA, Ramm A, Martinazzo EG, Silva, DM, Bacarin MA (2014) Crescimento e fotossíntese de plantas de 
pinhão-manso cultivadas em diferentes condições de luminosidade. Rev bras eng agríc ambient. 18 (1) 3-9.

Souza RP, Machado EC, Silva JAB, Lagôa AMMA, Silveira JAG (2004) Photosynthetic gas exchange, chlorophyll fluorescence and some associated metabolic changes in cowpea (Vigna unguiculata) during water stress and recovery. Environ Exp Bot. 51 (1) 45-56.

Stirbet A, Govindjee R (2011) On the relation between the Kautsky effect (chlorophyll $a$ fluorescence induction) and Photosystem II: basics and applications of the OJIP fluorescence transient. J Photochem Photobiol B Biol. 104 (1-2) 236-57.

Strasser BJ, Strasser RJ (1995) Measuring fast fluorescence transient to address environmental questions: The JIP-test. In: Mathis P (ed) Photosynthesis: from Light to Biosphere. Springer, Netherlands. 977-980.

Strasser RJ, Michael MT, Srivastava A (2004) Analysis of the chlorophyll a fluorescence transient. In: George C, Govindje, Papageorgiou GC (eds) Advances in photosynthesis and respiration chlorophyll fluorescence a signature of photosynthesis. 1st edn. Springer, Netherlands. 321-362.

Teixeira RN, Toledo MZ, Ferreira G, Cavariani C, Jasper SP (2011) Germinação e vigor de sementes de crambe sob estresse hídrico. Irriga. 16 (1) 42-51.
Tsimilli-Michael M, Strasser RJ (2008) In vivo assessment of stress impact on plant's vitality: applications in detecting and evaluating the beneficial role of mycorrhization on host plants. In: Varma A (ed) Mycorrhiza: state of the art, genetics and molecular biology, eco-function, biotechnology, eco-physiology, structure and systematics, 3rd edn. Springer, Netherlands. 679-703.

Waseem M, Ali A, Tahir M, Nadeem MA, Ayub M, Tanver A, Ahmad R, Hussain M (2011) Mechanisms of drought tolerance in plant and its management through diferent methods.Continental J Agricultural Science. 5 (1) 10-25.

Yusuf MA, Kumar D, Rajwanshi R, Strasser RJ, TsimilliMichael M, Govindjee R, Sarin, NB (2010) Overexpression of $\gamma$-tocopherol methyl transferase gene in transgenic Brassica juncea plants alleviates abiotic stress: physiological and chlorophyll $a$ fluorescence measurements. BBA-Bioenergetics. 1797 (8) 1428-1438.

Zhanga RH, Zhanga H, Camberato J, Xuea Q. (2015) Photosynthetic performance of maize hybrids to drought stress. Russ J Plant Physiol.62 (6) 788-796.

Zushi K, Matsuzoe N (2017). Using of chlorophyll a fluorescence OJIP transients for sensing salt stress in the leaves and fruits of tomato. Sci Hortic. 219:216-221. 